UDC 821.163.41-1.09 Broniewski W. https://doi.org/10.18485/ms_zmss.2020.97.10

\author{
Roman Bobryk \\ Uniwersytet Przyrodniczo-Humanistyczny w Siedlcach \\ roman.bobryk@uph.edu.pl \\ bobrykr@uph.edu.pl \\ Roman Bobryk \\ Siedlce University of Natural Sciences and Humanities \\ roman.bobryk@uph.edu.pl \\ bobrykr@uph.edu.pl
}

\title{
SŁOWO O SŁOWIE O STALINIE WŁADYSŁAWA BRONIEWSKIEGO1
}

\section{A FEW WORDS ON A FEW WORDS ON STALIN BY WŁADYSŁAW BRONIEWSKI}

Poemat Słowo o Stalinie uznawany jest za klasyczny przykład poezji polskiego socrealizmu. Powstał on na potrzeby antologii utworów dedykowanych sowieckiemu przywódcy z okazji jego siedemdziesiątych urodzin. Niemal od razu zyskał dużą popularność i był wielokrotnie przedrukowywany w czasopismach oraz jako odrębna publikacja, a do jego słów powstała kantata na chór męski z muzyką Alfreda Gradsteina. Wbrew opinii niektórych badaczy, którzy widzą w utworze próbę przedstawienia szerokiej perspektywy dziejowej, poemat jest dziełem o wyraźnym nastawieniu panegirycznym. Tym co odróżnia go od „,tradycyjnych” form panegirycznych jest konstruowanie opowieści o bohaterze za pomocą serii metonimicznych nawiązań. W swoim panegiryzmie potrafi Broniewski posunąć się do utożsamienia Stalina i rewolucji.

Słowa kluczowe: Władysław Broniewski, Josif Stalin, socrealizm, poezja panegiryczna, rewolucja.

The poem A few words on Stalin is considered a classic example of Polish socialist realist poetry. It was written for an anthology dedicated to the Soviet leader to celebrate his seventieth birthday. The poem was almost an immediate success and was reprinted in magazines and separately. It was set to the music of Alfred Gradstein to create a cantata for male choir. Some researchers see in the work an attempt to provide a broad historical perspective; however, the poem is clearly of a panegyric nature. What sets it apart from the "traditional" panegyric forms is the construction of its story, which follows a character through a series of metonymic references. In his adulation Broniewski goes so far as to equate Stalin with revolution. revolution.

Keywords: Władysław Broniewski, Josif Stalin, socialist realism, panegyric poetry,

1 Artykuł powstał w ramach realizacji tematu badawczego Ideologie artystyczne i spoteczne w literaturze europejskiej XX $i$ XXI wieku realizowanego w Instytucie Językoznawstwa i Literaturoznawstwa Uniwersytetu Przyrodniczo-Humanistycznego w Siedlcach. 
Twórczość Władysława Broniewskiego — zwłaszcza jeśli zestawi się ją $\mathrm{z}$ burzliwą biografią tego poety - $\mathrm{z}$ jednej strony wymyka się wszelkim próbom jednoznacznego przyporządkowania do któregokolwiek z dwudziestowiecznych „-izmów”, z drugiej zaś strony trudno oprzeć się wrażeniu, że jest ona nad wyraz jednolita, tak pod względem stylistycznym, jak i w warstwie tematycznej. Trudnym do pogodzenia wydaje się przy tym chociażby fakt, że człowiek odznaczony za zasługi wojenne (w tym i za wojnę z Rosją Radziecką w 1920 roku) Srebrnym Krzyżem Virtutti Militari i czterokrotnie Krzyżem Walecznych przez większość okresu międzywojennego i po wojnie sympatyzował z ruchem komunistycznym. Zadziwiający wydaje się zwłaszcza powojenny „romans” Broniewskiego z polskimi komunistami - mimo bowiem swoich przedwojennych sympatii dla ideologii socjalistycznej, znalazłszy się w 1939 roku w radzieckiej strefie okupacyjnej (a w ówczesnej terminologii sowieckiej propagandy — na terenach Zachodniej Ukrainy i później — Ukraińskiej Republiki Radzieckiej²), stał się poeta ofiarą sowieckiej prowokacji, po której znalazł się we lwowskim więzieniu na Zamarstynowie, a później za murami słynnego moskiewskiego więzienia na Łubiance. Trzeba jednak zaznaczyć, że według różnych świadectw, w odróżnieniu od wielu (większości?) kolegów po piórze, entuzjastycznie witających nastanie władzy sowieckiej, Broniewski miał się odnosić do nowych porządków w sposób powściągliwy i krytyczny, a przy tym nieustannie chciał recytować swoje patriotyczne wiersze ${ }^{3}$. Dość na tym, że po wydostaniu się ze Związku Radzieckiego $\mathrm{z}$ armią Andersa (z epizodem służby w charakterze oficera oświatowego w 6 . dywizji piechoty), poeta wielokrotnie wypowiadał się krytycznie o ZSRR jako kraju, gdzie idee socjalizmu dawno już zostały zarzucone oraz pisał i starał się publikować wiersze, w których poruszał między innymi kwestie wschodnich granic Polski i zdrady aliantów. A po tym wszystkim zdecydował się wrócić do Polski, rządzonej przecież przez zainstalowany dzięki sowieckiej pomocy i zdominowany przez posłusznych ZSRR polskich komunistów Tymczasowy Rząd Jedności Narodowej.

Jako przyczynę powrotu poety wskazuje się zazwyczaj fakt, że dowiedział się, iż wbrew wcześniejszym informacjom, mówiącym o śmierci jego ukochanej Marii Zarębińskiej w Oświęcimiu, kobieta przeżyła obóz i znajduje się w kraju. Można również zakładać, że znaczącą rolę przy podjęciu decyzji

2 W myśl tajnego protokołu dołączonego do paktu Ribbentrop - Mołotow (znanego też jako pakt Hitler - Stalin) podpisanego 23 sierpnia 1939 roku w Moskwie, tereny wschodniej Polski (w sowieckiej nomenklaturze tego okresu: Zachodnia Białoruś i Zachodnia Ukraina) znalazły się pod bezpośrednią jurysdykcją ZSRR, a po przeprowadzeniu na tych terenach fikcyjnych wyborów do rad narodowych (październik 1939), wbrew międzynarodowym konwencjom, zostały formalnie włączone (na wniosek tychże rad) w skład Białoruskiej SRR i Ukraińskiej SRR.

3 Zob. na ten temat np. wspomnienia Aleksandra Wata (Wat 1990: 289). Wat wspomina również, że skazany na karcer Broniewski przez cały czas kary (6 dni) potrafił chodzić po celi i śpiewać pieśni legionowe (s. 362). 
o powrocie do Polski odegrać musiały z jednej strony najzwyklejsza tęsknota za krajem i bliskimi osobami, z drugiej zaś — podświadome lub świadome nadzieje związane z nastaniem rządów partii przyznającej się do socjalistycznego rodowodu i samookreślającej się przy pomocy przymiotnika "robotnicza" (jakkolwiek pobyt w sowieckich więzieniach powinien go z tego typu naiwności wyleczyć ${ }^{4}$ ). Ostatecznie w listopadzie 1945 r. poeta wrócił do Polski, gdzie spotkał się z entuzjastycznym powitaniem ze strony władz i prostych obywateli. Od samego niemal początku stał się jednym z ulubieńców tychże władz, a sprawujący urząd prezydenta Bolesław Bierut miał mu nawet zaproponować napisanie nowego hymnu państwowego. Według różnych świadectw Broniewski miał się na taką propozycję oburzyć. W innych jednak sytuacjach wspierał swoją twórczością rządzących komunistów. W grudniu 1949 roku wyszło spod jego pióra słynne Słowo o Stalinie — wiersz uchodzący dziś za jeden ze sztandarowych przykładów literatury socrealizmu (choć zarówno klasyfikacja, jak i kryteria wartościowania pozostają zwykle nieznane).

W komentarzu edytorskim w czterotomowym krytycznym wydaniu Poezji zebranych Broniewskiego na temat Słowa o Stalinie znaleźć można następującą informację:

Pierwszy utwór Broniewskiego poświęcony żyjącemu przywódcy politycznemu. Powstał w ciągu trzech dni 10-12 grudnia 1949 [...], na jednym rauszu alkoholowym, jak powiedział mi Broniewski, w atmosferze kultu dla Stalina szerzonego przez wszystkie środki masowego przekazu a szczególnie nasilonego w końcu 1949 r. z powodu siedemdziesiątej rocznicy urodzin wodza państwa radzieckiego, przypadającej 27 grudnia. Według danych Polskiej Bibliografii Literackiej tylko w 1949 roku w czasopismach polskich rejestrowanych w tej bibliografii (a więc nie wszystkich) ogłoszono kilkadziesiąt publikacji poświęconych Stalinowi, w tym dwadzieścia parę wierszy, prozy, artykułów polskich literatów, m. in. Gałczyńskiego, Juliana Tuwima, Zofii Nałkowskiej, Lucjana Rudnickiego, Witolda Wirpszy, Wiktora Woroszylskiego, Leona Pasternaka, Stanisława Wygodzkiego. Jak pisał Lesław Bartelski, Stowo o Stalinie „powstało w atmosferze podziwu dla Stalina jako zwycięskiego wodza, kierownika państwa radzieckiego, uosobienia tych sił proletariatu, które w jakiejś mierze przekształciły świat". 5

4 Mariusz Urbanek, autor biografii poety, wspomina, że w czasie służby w armii Andersa Broniewski pisał do byłej żony (Janiny Broniewskiej), że nigdy nie wyrzekł się swych socjalistycznych przekonań. Biograf zaznacza, że „Dla niewyznających się w ideologicznych subtelnościach oficerów jego lewicowość oznaczała poparcie dla komunistycznej Rosji” (zob. Urbanek 2011: 191-192). Tymczasem, jak się wydaje, w oczach poety ideologia socjalistyczna nie była zła sama w sobie, a jedynie została wypaczona przez sowieckich partyjnych aparatczyków. Wyraz swojemu krytycznemu stosunkowi do ZSRR i rządzącej nim partyjnej wierchuszki dawał Broniewski między innymi w trakcie spotkań autorskich z sympatyzującymi z komunizmem mieszkańcami żydowskich kibuców w ówczesnej Palestynie oraz w krótkich, ironicznych i złośliwych wierszykach.

5 Cyt. za: Broniewski 1997: 372. Informację podaną przez Lichodziejewską powtarzają inni badacze i biografowie Broniewskiego (zob. np.: Urbanek 2011: 276). 
Wydaje się, że rację ma Maciej Tramer, który (przytaczając co prawda jedynie początkowy fragment powyższego komentarza) uznaje go za próbę usprawiedliwienia poety ze strony redaktorki wydania (a jednocześnie - wcześniej — jego biografki). Tramer, który nazywa Stowo o Stalinie „najbardziej kontrowersyjnym i wstydliwym" wierszem Broniewskiego, zwraca przy tym uwagę na końcowe człony pierwszego zdania dotyczące „kultu dla Stalina” i rocznicy urodzin Wodza, bagatelizując zdania kolejne. W jego opinii Lichodziejewska „rozmywała alkoholem komentarz do Stowa o Stalinie” i w ten pośredni sposób ,informowała czy telnika o chwilowej niepoczytalności jego autora” (Tramer 2010: 56). Akcentując przede wszystkim ,alkoholowy” aspekt genezy poematu, Tramer stara się uwzględnić całokształt wysiłków redaktorki zmierzających do osłabienia wymowy Stowa... i leżącej u źródeł utworu ówczesnej postawy Broniewskiego. Bo przecież w zasadzie każde zdanie w tym krótkim komentarzu (nota bene $\mathrm{z}$ tego punktu widzenia stoi on w sprzeczności z sensem krytycznych publikacji jakiejkolwiek twórczości) ma na celu umniejszenie znaczenia tego tekstu i rozmycie go w natłoku innych publikacji poświęconych Stalinowi. Strategia Lichodziejewskiej ma przy tym charakter wielotorowy. Oprócz wątku alkoholowego znajdziemy na przestrzeni przywołanych wyżej paru zdań jeszcze kilka innych ,usprawiedliwień”: wszechobecny w środkach masowego przekazu końca lat 1940 . kult Stalina ${ }^{6}$, powszechny w środowisku literackim serwilizm, skłaniający pisarzy do pisania wiernopoddańczych panegiryków ku czci „Wodza światowego proletariatu”. Nie ulega najmniejszej wątpliwości, że intencją Lichodziejewskiej jest częściowe przynajmniej wybielenie wizerunku Broniewskiego, postrzeganego (między innymi właśnie z powodu Słowa...) jako nadworny poeta władzy ludowej ${ }^{7}$.

Wszystkie te zabiegi świadczą o jednym — w momencie publikacji kolejnych wydań dzieł Broniewskiego Stowo o Stalinie stało się utworem kompromitującym poetę $\mathrm{w}$ oczach odbiorców ${ }^{8}$. Przyczyną takiego stanu rzeczy musiał być oczywiście sam bohater utworu, który wkrótce po śmierci w 1953

${ }^{6}$ Który w intencji autorki komentarza miał zapewne wpłynąć na poetę.

7 Dla uzupełnienia informacji związanych z genezą Stowa o Stalinie dodać należy jeszcze jedną informację. Eliza Czapska wspomina, że

Z okazji 70. urodzin Stalina w 1949 roku władze ogłosiły zamknięty konkurs, w którym wzięli udział literaci polscy, m.in.: Maria Dąbrowska, Zofia Nałkowska, Jarosław Iwaszkiewicz, Julian Tuwim, Konstanty Ildefons Gałczyński, Mieczysław Jastrun. Poemat Broniewskiego okazał się najlepszy. (Czapska 2018: 123)

8 Można się domyślać, że Czapska powtarza w tym miejscu informacje zawarte w biografii Broniewskiego autorstwa Mariusza Urbanka (Urbanek 2011: 276). Urbanek jednak nie wskazuje żadnych źródeł, z których miałyby pochodzić te dane, a jego praca ma charakter czysto popularny i w całości pozbawiona jest aparatu badawczego.

W wydanym w 1992 roku opracowaniu wybranych utworów Broniewskiego w serii Biblioteka Analiz Literackich Tadeusz Bujnicki pisze:

Klęską poety jest niewątpliwie udział w hołdowniczych wystąpieniach na siedemdziesięciolecie Stalina poematem Stowo o Stalinie, w którym obok publicystyczno-wiecowych sformułowań, można znaleźć fragmenty o wielkiej sile wyrazu („Na mojej ziemi tysiące mogił...”). (Bujnicki 1992: 31) 
roku i tajnym referacie Chruszczowa na temat kultu jednostki i jego następstw (1956) szybko został strącony z komunistycznego piedestału i uznany za zbrodniarza. Co ważne, sam Broniewski, mimo zmian zachodzących w sferze politycznej, początkowo nie chciał się zgodzić na usunięcie poematu z przygotowywanego przez Państwowy Instytut Wydawniczy wydania swoich Wierszy zebranych $\left(1956^{9}\right)$ i zaaprobował ten ,zabieg” dopiero po głębszym namyśle spowodowanym informacjami na temat „rewelacji Chruszczowa” 10 . Opowiadająca o związanej z tym rozmowie Irena Szymańska przytacza słowa poety, który miał w rozmowie telefonicznej uznać Słowo... za jeden ze swoich najlepszych wierszy (Szymańska 2002: 243). Utwór ten był niewątpliwie bardzo ceniony przez tzw. ,czynniki oficjalne” i oficjalny nurt obiegu literackiego. Świadczyć o tym może fakt kilkukrotnego odrębnego wydania poematu i jego liczne przedruki w prasie i rozmaitych antologiach oraz powstała do jego słów kantata ku czci przywódcy Kraju Rad. Innego rodzaju świadectwem są opinie ówczesnej krytyki, zawierające jednoznacznie pozytywne oceny dzieła (zob. np. Matuszewski 1954: 485-486, 488-490). W tym ostatnim przypadku należałoby jednak wziąć poprawkę na fakt na, delikatnie rzecz ujmując, ograniczoną samodzielność osądów ze strony recenzentów i badaczy o wartościowaniu decydowała zwykle wynikająca z relacji z ,władzą" pozycja autora $^{11}$.

W poświęconym Poematowi dla dorostych Adama Ważyka studium (Głowiński 1992: 133-156) Michał Głowiński trafnie wskazywał, że w dobie socrealizmu ,poezja realizowała zasady dwóch szeroko i luźno rozumianych gatunków literackich: ody i sielanki”, zauważając przy tym, że „są to gatunki klasyczne, co potwierdzałoby znaną tezę Siniawskiego, że realizm socjalistyczny wywodzi się z dworskiego klasycyzmu, klasycyzmu u cesarskiej klamki” (Głowiński 1992: 135). W odróżnieniu od ściśle gatunkowego pojmowania ody i sielanki, jaki oferują poetyki normatywne, w odniesieniu do socrealizmu Głowiński traktuje je jednocześnie jako swoiste kategorie estetyczne. O istocie socrealistycznej sielanki decyduje zdaniem badacza ,wizja historii zakończonej”,

9 Zbiór ten był później kilkukrotnie wznawiany.

10 Zob. np. Szymańska 2002: 243; Tramer 2010: 58.

11 Magdalena Piekara zwraca uwagę na fakt, że o ile w stosunku do większości twórców tego okresu krytyka wysuwała jakieś zastrzeżenia (badaczka tłumaczy to obawą o oskarżenie o brak czujności w przypadku, gdyby okazało się, iż dany autor reprezentował ,niesłuszne” poglądy) i zachowywała się - co powtarza Piekara za Mariuszem Zawodniakiem - jak prokurator wobec oskarżonego, to $\mathrm{W}$ odniesieniu do Broniewskiego nic takiego nie miało miejsca (Piekara 2009: 168-169). Oznacza to, że poeta traktowany był jako twórca ,sprawdzony ideologicznie" i cieszący się zaufaniem władz partyjnych. Jednocześnie zauważa Piekara, że po ukazaniu się dwóch tomów poetyckich (Stowa o Stalinie (1949) i Nadziei (1951)) w zasadzie nie ukazało się nazbyt wiele artykułów poświęconych poezji Broniewskiego, mimo że w tym właśnie okresie obchodzono uroczyście dwudziestopięciolecie jego twórczości (Piekara 2009: 170). 
czy innymi słowy — wizja socjalistycznej Arkadii, świata, w którym zrealizowała się komunistyczna utopia (Głowiński 1992: 136). Z kolei o odzie mówi:

Oda to przede wszystkim wielka retoryka, ta retoryka, która służy bądź opiewaniu władcy, bądź potępianiu jego przeciwników; to poezja pochwały, a zarazem - gdy przeciw wrogowi skierowana — walki. (Głowiński 1992: 135)

Chcąc przyporządkować poemat Broniewskiego do którejś spośród wymienionych przez Głowińskiego estetyk/konwencji, jednoznacznie musielibyśmy wskazać na konwencję ody. Wybór taki podyktowany byłby z jednej strony warstwą tematyczną utworu (pochwała „władcy”), z drugiej zaś patetyczną stylistyką. Wydaje się jednak, że należałoby tu poczynić drobne zastrzeżenie: utwór pochwalny w podniosłej tonacji niekoniecznie musi być odą - równie dobrze mógłby zostać zakwalifikowany jako artystyczny wariant tekstu hagiograficznego (wszak w gruncie rzeczy opisuje całą partyjną karierę Stalina, począwszy od kółek rewolucyjnych na Kaukazie). Różnica pomiędzy tymi dwoma formami wypowiedzi zasadza się w sferze intencjonalnej. Jako że kwestie te w odniesieniu do Stowa o Stalinie są dziś niemożliwe do zrekonstruowania, poprzestać musimy na uznaniu poematu za utwór panegiryczny...12

W opracowaniach dotyczących twórczości Broniewskiego Słowo o Stalinie wspominane jest, co oczywista, przy okazji omówienia socrealistycznego epizodu jego biografii twórczej ${ }^{13}$. Dla wszystkich jasnym jest, że nie sposób pominąc tekstu, który z jednej strony w swoim czasie tak silnie oddziaływał artystycznie na społeczeństwo (niechby i przy „współudziale” czynników państwowych), z drugiej zaś - zaciążył na odbiorze samego twórcy przez współczesnych i następne pokolenia. Począwszy od najwcześniejszych omówień, akcentuje się odejście przez poetę od tradycyjnego ujęcia biograficznego (Matuszewski 1954: 488) na rzecz zakreślenia szerokiej perspektywy dziejowej. Mariusz Urbanek ujmuje to w sposób następujący:

Poemat Broniewskiego jest $\mathrm{w}$ istocie utworem o tym, jak zmieniał się na przełomie XIX i XX wieku świat. Kończyło się stulecie, w którym według Manifestu komunistycznego świat miał zatrząść się w posadach, ale się nie zatrząsnął, zaczynał wiek, w którym krążące nad Europą widmo komunizmu stało się rzeczywistością. (Urbanek 2011: 276)

12 Edward Balcerzan zaznacza, że poemat Broniewskiego „w jakiejś tylko części odpowiada kanonom panegiryku", a nawet mógłby być odbierany ,jako obrona przed panegirykiem personalnym" (Balcerzan 1984: 148).

13 O epizodzie socrealistycznym wspominają przede wszystkim opracowania opublikowane po roku 1990. W pracach powstałych wcześniej mówi się po prostu o tematyce rewolucyjnej w poezji Broniewskiego, przy czym w przypadku opracowań opublikowanych po roku 1956 Stowo o Stalinie jest dyskretnie pomijane (widać to choćby w Bujnicki 1974; Siatkowski 1964). 
Znamienne jednak, że cała ta perspektywa dziejowa bynajmniej nie sprowadza się do prezentacji dziejów ruchu robotniczego ani nawet rewolucji 1917 roku, ale nierozerwalnie zespala rozwój ideologii komunistycznej i rewolucję $\mathrm{z}$ osobą tytułowego bohatera. Zabieg taki można interpretować jako swoiste utożsamienie idei rewolucyjnej z osobą przywódcy ZSRR, a tym samym i przypisanie mu zarówno funkcji sprawczej kolejnych wydarzeń i wiodącej w nich roli (zob. Balcerzan 1984: 149).

Poemat o Stalinie (podobnie zresztą jak i poemat poświęcony osobie generała Karola Świerczewskiego) składa się z dziewięciu zróżnicowanych pod względem formalnym części. Ich treścią są kolejno:

I. Początki działalności rewolucyjnej Stalina;

II. Wydarzenia rewolucyjne 1905 i 1917 roku;

III. Obrona Carycyna w okresie rewolucji i obrona Stalingradu w czasie II wojny światowej;

IV. Powojenny rozwój ZSRR;

V. Pochwała Stalina — przywódcy rewolucji;

VI. Pochwała Stalina - porównanie socjalistycznego dobrobytu ze światem kapitalistycznym;

VII. Refleksja na temat wojennych losów Polski i powojennego sojuszu z ZSRR;

VIII. Pochwała Stalina — podkreślenie roli Stalina dla światowego proletariatu;

IX. Zakończenie - pochwała postępu.

Pod względem treściowo-kompozycyjnym dają się w poemacie Broniewskiego wyodrębnić trzy części: wprowadzenie (część I), część zasadnicza pochwała Stalina, Kraju Rad i rewolucji (części II - VI) i zakończenie (części VII-IX). Przy czym samo zakończenie również ma strukturę trójdzielną.

Część I, którą cechuje stosunkowo daleko posunięta konstrukcyjna nieregularność, przedstawia okoliczności, w jakich młody Stalin („,lat dwadzieścia miał Stalin”) rozpoczynał działalność rewolucyjną. Wprawdzie oficjalne (zwłaszcza te powstałe za życia genseka) biografie wspominają, że już jako piętnastolatek prowadził on agitację wśród uczniów seminarium i robotników w Tyflisie (Tbilisi), jednak Broniewski pomija ten epizod, wprowadzając swego bohatera jako dorosłego mężczyznę i dojrzałego rewolucjonistę. Poeta pozostaje jednak wierny „oficjalnej” biografii Stalina w najważniejszym jej aspekcie - przedstawia go jako kontynuatora dzieła Lenina. Młody Dżugaszwili jest przy tym niejako przeznaczony do działalności rewolucyjnej (został „zrodzony wśród walki klas”).

Wiek XIX, który jest zasadniczym tematem części I jest w świecie utworu wiekiem, w którym narodziła się filozofia marksistowska i idee ruchu robotniczego. Jest to okres wyzysku robotników, pierwszych robotniczych zrywów 
(manifestacji i Komuny Paryskiej) i ich klęsk. To czas, „,w którym proletariat / nie mógł ziemi wysadzić z posad"14. Ta ostatnia okoliczność nie pozostaje bez znaczenia dla całości poematu — jego bohater opisywany jest jako zwycięski wódz ludu pracującego całego świata.

Tematyka części I (tj. narodziny ruchu robotniczego) może być przy tym kluczem do interpretacji sensu formalnego nieuporządkowania tego fragmentu utworu. Wydaje się on być poetyckim (wierszowym) odpowiednikiem chaosu i niepokoju (burzliwości) towarzyszących wyłanianiu się z ,niebytu” nowej idei. Podążając tym tropem, należałoby z kolei przyjąć, że regularny układ stroficzny, jaki pojawia się w kolejnych częściach, jest ekwiwalentem okrzepnięcia tej ideologii.

Część II może być postrzegana jako metaforyczny obraz ostatnich dekad carskiej Rosji, w której „Wrą / w głębokościach zaskórne wody”, tzn. pod maską pozornego spokoju i wewnętrznego porządku trwa rewolucyjne wrzenie, którego nie mogą w żaden sposób powstrzymać kolejne aresztowania i zsyłki. Ten etap biografii Stalina streszczają dwa końcowe wersy pierwszej strofy: „Życie burzliwe, życie piękne / od Kaukazu do tundry i tajgi!”, które można interpretować jako nawiązanie do kilkukrotnych zsyłek przyszłego przywódcy ZSRR na Syberię w latach 1909-1917. Trzecia strofa tej części wspomina o rozgonionej (przez policję) ,demonstracji w Tyflisie”, która stała się jednym z wydarzeń przygotowujących rewolucję. Chodzi tu najprawdopodobniej o manifestację z okazji 1. Maja z 1901 roku $^{15}$, w trakcie której jeden z uczestników (G. Telija) miał rozwinąć czerwony sztandar z podobiznami Marksa i Engelsa i hasłem „Proletariusze wszystkich krajów łączcie się!” w językach rosyjskim i gruzińskim. Jednym z organizatorów tej demonstracji miał być młody Josif Dżugaszwili, który już w trakcie przygotowań zaczął ukrywać się przed policją i tym samym stał się niejako zawodowym rewolucjonistą ${ }^{16}$. W przypadku powiązania osoby Stalina ze wspomnianą demonstracją (co wcale nie musiało być trudne w atmosferze kultu Wodza i przy dostępności publikacji biograficznych na jego temat) zakończenie wspomnianej strofy może być odczytywane jako przypisanie (przynajmniej pośrednio) Stalinowi zasiania ziarna rewolucji w carskim imperium.

14 Słowa te są czytelnym nawiązaniem do Międzynarodówki - powstałej w 1871 roku pieśni rewolucyjnej, do której słowa napisał (wspominany również w I części) francuski rewolucjonista i poeta, Eugėne Pottier (1816-1887), jeden z przywódców Komuny Paryskiej. Fragment ten nawiązuje do słów polskiej wersji językowej („ruszamy z posad bryłę świata”). Rosyjska wersja językowa zapowiada zburzenie aż do fundamentów „całego świata zniewolenia" i budowę nowego świata (to ostatnie zapowiada również tekst oryginalny).

15 O demonstracji tej pisała kierowana przez Lenina „Iskra” (1901, nr 6), która nazwała ją początkiem ruchu rewolucyjnego na Kaukazie (см.: https://dic.academic.ru/dic.nsf/ sie/17594/ТИФЛИССКАЯ - dostęp 2.01.2020). Nie była to jednak jedyna demonstracja w Tyflisie - 5. stycznia 1904 roku (wg tzw. ,starego stylu”) miała tam miejsce demonstracja, w której uczestniczyło ok. 700 osób, a która wpisuje się w ciąg wydarzeń leżących u podstaw rewolucji 1905 roku.

16 Zob. Залесский (https://profilib.org/chtenie/143073/konstantin-zalesskiy-stalin-portret-na-fone-voyny-4.php). 
Ostatnie dwie strofy odnoszą się do dwóch rosyjskich rewolucji — z roku 1905 i z roku 1917, a jednocześnie są pochwałą partii bolszewickiej jako obrończyni uciśnionego proletariatu. Rewolucja konceptualizowana jest w kategoriach otwarcia domu (pierwszą nazywa się ,progiem”, drugą — „drzwiami otwartymi"). Tym samym Rosja przedstawiana jest jako dom. Broniewski posługuje się tu również rdzennie rosyjskim, powstałym jeszcze w czasach carskich i przypisywanym Piotrowi I, określeniem Rosji jako „Szóstej Części” świata. Najprawdopodobniej jednak poeta zaczerpnął to określenie z tytułu powstałego w roku 1926 na zamówienie centrali handlowej Gostorg filmu propagandowego „Szósta część świata”, wyreżyserowanego przez Dżigę Wiertowa. Stwierdzenie, że „Część Szósta — świeci światu” odwołuje się do wyobrażeń rewolucji jako ognia/płomienia lub pochodni. Świecenie oznaczać może, że w Rosji płomień rewolucyjny już zapłonął, a jego światło wskazuje drogę reszcie świata.

Część III, jeśli skupilibyśmy się wyłącznie na ostatniej strofie, jest pochwalnym hymnem ku czci „Związku Republik Rad”. Jednak inicjalne wersy tej części kierują uwagę raczej na kierownictwo państwa niż na samo państwo. Broniewski sięga tu po silnie utrwalony w kulturze radzieckiej, a biorący swój początek w pracy Karola Marksa Walki klasowe we Francji, 1848 1850, mitologem rewolucji jako parowozu dziejów (na przestrzeni całego poematu czyni to zresztą kilka razy). Pochodną wspomnianego mitologemu jest wyobrażenie Stalina jako „Wielkiego Maszynisty”. Motyw ten powtarza się w części V, gdzie pada stwierdzenie, że

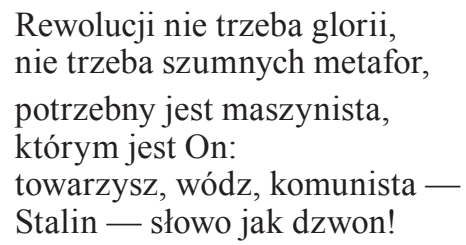

W zmodyfikowanym wariancie — Stalina jako „Wielkiego Sternika” motyw ten powraca także w części VI. Przy czym w tym ostatnim przypadku mamy do czynienia z odnowieniem (użyciem) przez propagandę sowiecką antycznego (horacjańskiego) toposu ojczyzny-okrętu.

Także kolejne strofy części III, jakkolwiek treścią ich jest na pierwszy rzut oka pochwała ludzi radzieckich, na piedestał stawiają osobę Wodza. W sposób bezpośredni czyni się to w strofie drugiej, gdzie pochwała wytrwałości ludzkiej („Chwała tym, co wśród ognia i mrozu, / jak złom granitowy, trwali,") przeistacza się w pochwałę Stalina, gdyż to on okazuje się w ostatecznym rozrachunku synonimem tej (wy)trwałości. Dzieje się tak za przyczyną paradygmatycznego szeregu porównań, którego zwieńczeniem i semantyką jest imię (pseudonim) „Stalin”. Pseudonim ten, często kojarzony w powszechnym odbiorze ze stalą, a więc niejako i wpisujący w swoją semantykę jej właściwości, miał zresztą konotować w powszechnym odczuciu właśnie 
trwałość, niezłomność i siłę moralną Wodza (por. Faryno 1999). Te same cechy miały charakteryzować przywoływanych w dwóch kolejnych strofach obrońców Carycyna z okresu wojny domowej w Rosji i obrońców Stalingradu z okresu II wojny światowej. Przykłady te nie są bynajmniej przypadkowo zestawione. W obu chodzi o to samo miasto - Carycyn przemianowano na Stalingrad 10 kwietnia 1925 roku. Obie bitwy obronne związane są przy tym z osobą Stalina. W przypadku obrony Carycyna w 1918 i 1919 roku był on jednym z organizatorów obrony tego ważnego ośrodka przemysłowego i węzła transportowego przed wojskami kozackimi generała Krasnowa. Później, po stopniowym umacnianiu się Stalina na szczytach partyjnej władzy, miasto nazwano od jego imienia Stalingradem. W czasie II wojny światowej miasto (w metaforycznym sensie jakby zwielokrotniony Stalin) stanęło na przeszkodzie planom Hitlera zawładnięcia polami naftowymi Kaukazu i całą Rosją.

W sposób pośredni pochwałę Stalina zawiera również kolejna część. Jej treścią jest przede wszystkim projekt zawracania wielkich rzek Syberii, ale można doszukiwać się w niej nawiązań do wszelkich wielkich planów inwestycyjnych ZSRR, jak na przykład Wielkiego Planu Przekształcenia Przyrody (nazywanego też Stalinowskim Planem Przekształcenia Przyrody), przy -jętego do realizacji w październiku 1948, a więc rok przed powstaniem poematu Broniewskiego. W pierwszej strofie wspomina się o zagrożeniu atomowym. Sądząc z przywołanego tu przypadku zniszczenia Hiroszimy, poeta wskazuje jednoznacznie na zagrożenie bronią atomową ze strony państw Zachodu ${ }^{17}$. Niszczycielskiemu Zachodowi przeciwstawia się nastawiony na rozwój techniczny i poprawę warunków bytowych ludności i pokojową egzystencję Związek Radziecki i sprzymierzoną z nim Polskę (tak można rozumieć słowa „Budujemy Pospolitą Rzecz”). Broniewski, wzywając ZSRR słowami „Kraju Republik, nowe twórz bajki: / wstecz niech popłynie rzeka”, nawiązuje do popularnego sowieckiego hasła propagandowego „Bajka stała się rzeczywistością" [Сказка стала былью] ${ }^{18}$.

Analogiczny schemat treściowy zawiera część VI. O pewnej zależności (spójności) tych partii utworu świadczyć może pojawiający się w zakończeniu tej części motyw rozpadu atomu. O ile jednak w części IV mówi się o rzeczywistym rozszczepieniu atomu i skonstruowaniu bomby atomowej, to w drugim przypadku motyw ten obecny jest na poziomie języka opisu - poeta, ogłaszając krach „starego” świata i narodziny „,nowego” (= zwycięstwo rewolucji), metaforycznie przyrównuje kres pierwszego do rozpadu atomu.

Analogicznie jak w części IV, również w części VI „Szósta Część” — Kraj Rad — przeciwstawiany jest reszcie świata, a relacja pomiędzy nimi określona została jako „bitwa”. Opozycja budowana jest na przeciwstawieniu „Tam -

$17 \mathrm{~W}$ momencie powstania wiersza odbyła się już pierwsza radziecka próba atomowa (29.08.1949). Trudno dziś ustalić, czy Broniewski mógł mieć na ten temat jakieś informacje.

18 Szczególnie popularne stało się ono w okresie późniejszym — powszechnie użytkowano je zwłaszcza po locie kosmicznym Jurija Gagarina, jednak pojawiło się w sowieckiej propagandzie już w latach trzydziestych XX w. 
bezrobocia, strajki, głód./Tu - praca.”. Przy czym „praca” jest tożsama ze zwycięstwem proletariatu. Gwarantem zaś tego zwycięstwa i przewodnikiem ludu pracującego jest Stalin.

Część VI zamyka w zasadzie główny korpus treściowy poematu. Stąd, jak się wydaje, nagromadzenie w tej partii tekstu elementów panegirycznych. Już w zakończeniu części V o Stalinie najpierw mówi się jako o „maszyniście”, który jest niezbędny dla rewolucji, a tym samym i niezbędny dla historii, a zaraz potem imię Stalina określa się jako „słowo jak dzwon”. Z jednej strony można doszukiwać się w tym nawiązań do „stalowych” kontekstów pseudonimu Wodza. Wydaje się jednak, że o wiele bardziej istotne są w tym wypadku kulturowe konotacje związane z dzwonem i wydawanym przezeń dźwiękiem. W tradycji chrześcijańskiej dźwięk dzwonu postrzegany jest jako głos Boga, a jego lokalizacja czyni zeń pośrednika między niebem a ziemią (zob. Cirlot 2012: 123; Forstner 2001: 397-398; Leksykon... 1992: 39). Oczywiście, poetyka socrealizmu siłą rzeczy zmusza do odrzucenia zwłaszcza tego ostatniego aspektu, a i w miejsce Boga należałoby w tym przypadku podstawić albo rewolucję/komunizm, albo samego Stalina. Oprócz tego dźwięk dzwonu odgrywać może ważna rolę w życiu społeczności — ostrzegać o zagrażającym niebezpieczeństwie, informować o nieszczęściu itp.

W części VI najpierw podkreśla się, że to Stalin „przez dziesiątki lat / wiódł ludzkość na krańce dziejów", by w następnych wersach dokonać utożsamienia Wodza z całym „walczącym światem” i „nadzieją” (konstrukcja zdaniowa czyni z tych pojęć synonimy imienia Stalina). W końcowych wersach tej części mówi się jeszcze o „siedemdziesięciu Stalinowych latach”, które „powiewają nad światem”. Tym samym „Stalinowe lata” (a więc sam Stalin) konceptualizowane są jako sztandar światowej rewolucji19. To zaś oznacza, że Stalin i rewolucja to to samo.

Nastający „nowy świat”, którego przywódcą jest w świecie poematu Stalin ma powstać na zgliszczach świata „starego”, u którego podstaw leży między innymi prawo rzymskie. Nowy porządek wszystkie te reguły odrzuca („tablice praw Rzymu / obalamy od Chin aż po biegun!”). Ma być oparty na wiedzy (=pewności/faktach), a nie na wierze („Pragniemy wiedzieć, nie wierzyć”, „Chwała faktom!”). Oznacza to odrzucenie religii na rzecz nauki.

Zasadnicza część poematu kończy się obwieszczeniem narodzin nowego świata. Trzy kolejne części stanowią rozbudowaną codę utworu. Jest to układ wielostopniowy — od osobistej wypowiedzi lirycznego „ja” (część VII), poprzez zbliżone w swej formie do gazetowych lub wiecowych hasel-informacji obrazujących znaczenie osoby Stalina dla całego świata (część VIII) po uogólniającą i na poły filozoficzną pochwałę postępu i Wodza światowego proletariatu.

19 Czerwony sztandar, albo „sztandar rewolucji” jest jednym z najważniejszych symboli ruchu rewolucyjnego w ogóle i Rewolucji 1917 roku w Rosji. 
Część VII jest jedyną partią tekstu, gdzie podmiot liryczny wypowiada się w 1. osobie - jako ,ja”. Wiąże się to zapewne z tematyką tego fragmentu poematu - dotyczy on cierpień narodu polskiego w czasie wojny. Smutek lirycznego ,ja” związany jest jednak wyłącznie z przeszłością — teraźniejszość napełnia go radością i nadzieją. Bierze się ona ze świadomości braterskiego sojuszu z ZSRR (o bliskości obu narodów świadczyć może na poziomie wierszowej organizacji paralelizm i jednocześnie wspólna cecha (duma) w opisie stolic obu krajów) i wspólnoty wszystkich ludzi pracy.

Część VIII wyróżnia się spośród reszty utworu już na poziomie graficznym. Składa się na nią dziewięć zdań, z których każde kończy się wypisanym wersalikami słowem „STALIN”, przy czym w ostatnim, najkrótszym zdaniu słowo to zostało powtórzone trzy razy. Treścią tych zdań jest rola przywódcy Kraju Rad w codziennym życiu ludzi pracy na całym świecie. Fakt przywoływania imienia Stalina przez mieszkańców różnych krajów i okoliczności, w jakich to się dzieje, prowadzą do wniosku, że jest on postrzegany jako symbol walki o wolność i prawa robotników, niejako ucieleśnienie idei światowej rewolucji, a jednocześnie upatruje się w nim wszechmocnej instancji, będącej w stanie zmienić los wzywających.

Ostatnie trzy strofy poematu składające się na część IX na pierwszy rzut oka przypominają dziecięcą rymowankę, w której ważniejszy od treści jest rym. Jeśli jednak doszukiwać się w tym fragmencie jakiegokolwiek sensu, to warto zwrócić uwagę na samo następstwo poszczególnych motywów w tekście oraz na zależności wynikające z jego organizacji wierszowej. Początkowe wersy opiewają piękno i potęgę natury (morze i lot orła). Piękno to jest jednak niczym w porównaniu z nowoczesnymi wytworami myśli ludzkiej. Ostatnia strofa odbiega tematycznie od dwóch poprzedzających. Można ją jednak potraktować jako inny poziom wcześniejszej gradacji. „Stalin” i „,pokój” sytuowaliby się w ten sposób na samym szczycie wierszowej hierarchii wartości. Swoisty „odzew”, jaki pojawia się po słowach pochwały pod adresem Wodza

(Chwała imieniu Stalina!

Pokój światu, pokój...)

pozwalają odczytać „,imię Stalina” i „,pokój” jako pojęcia synonimiczne. Innymi słowy — Wódz jest (jedynym?) gwarantem światowego pokoju...

Stowo o Stalinie jest, wbrew opiniom niektórych badaczy, utworem niemalże czysto panegirycznym, jakkolwiek zastosowana tu forma panegiryzmu odbiega od tradycyjnych wyobrażeń. Poeta posłużył się (przynajmniej w niektórych partiach tekstu) bardziej subtelnymi środkami, niż czynili to niektórzy przynajmniej spośród piewców Wodza. Zamiast mówienia wprost i zwrotów kierowanych do generalissimusa, znaczna część utworu skonstruowana jest na zasadzie metonimicznych nawiązań do biografii Stalina i ukształtowanej już w kulturze sowieckiej Rosji jego mitologii (młodzieńcza działalność, zsyłki, obrona Carycyna, obrona Stalingradu, wielkie powojenne projekty rozwoju 
ZSRR). Za pomocą konstrukcji językowych poeta konceptualizuje Stalina jako sztandar światowej rewolucji (czy wręcz czyni zeń synonim rewolucji) i nadzieję wszystkich ludzi pracy. Broniewski ujawnia przy tym swoją doskonałą znajomość kwestii związanych z kulturą rosyjską i radziecką, aktualnymi wydarzeniami mającymi miejsce w Kraju Rad oraz oficjalną sowiecką propagandą..

\section{LITERATURA}

Balcerzan Edward. Poezja polska w latach 1939-1965. Część I: Strategie liryczne. Wydanie drugie. Warszawa: Wydawnictwa Szkolne i Pedagogiczne, 1984.

Bujnicki Tadeusz. Wiersze Władysława Broniewskiego. Warszawa: Wydawnictwa Szkolne i Pedagogiczne, 1992.

Bujnicki Tadeusz. Władysław Broniewski. Warszawa: Państwowy Instytut Wydawniczy, 1974.

Cirlot Juan. Słownik symboli. Przekład Ireneusz Kania. Kraków 2012.

Czapska Eliza. „Rozmowa Władysława Broniewskiego z historią. Mity i role artysty w symbolicznym imaginarium Polski”. Acta Universitatis Lodziensis. Folia Sociologica 63 (2018): $111-127$.

Faryno Jerzy. Stal i anatomia. Studia Litteraria Polono-Slavica. 3: Dekada poszukiwań. Literatura rosyjska lat dwudziestych XX wieku. Warszawa, 1999: 247-251.

Forstner Dorothea. Świat symboliki chrześcijańskiej. Leksykon. Przekład i opracowanie Wanda Zakrzewska, Paweł Pachciarek, Ryszard Turzyński. Warszawa: Instytut Wydawniczy PAX, 2001.

Głowiński Michał. Rytuat i demagogia: trzynaście szkiców o sztuce zdegradowanej. Warszawa: Open, 1992.

Leksykon symboli. Opracowała Marianne Oesterreicher-Mollwo. Przełożył Jerzy Prokopiuk. Warszawa: Wydawnictwo ROK Corporation SA, 1992.

Matuszewski Ryszard. „Poezja Władysława Broniewskiego w latach 1939-1945”. Pamiętnik Literacki 4 (1954): 477-503.

Piekara Magdalena. „Broniewski czytany przez socrealistycznych krytyków”. Broniewski: Warszawa - Katowice 2009. Pod red. Mariusza Jochemczyka, Sławomira Kędzierskiego, Miłosza Piotrowiaka i Macieja Tramera. Warszawa - Katowice: Agencja Artystyczna „Para”, 2009: 166-175.

Siatkowski Zbigniew. „O mechanice poezji rewolucyjnej: casus Broniewskiego”. Pamiętnik Literacki 3 (1964): 133-160.

Smulski Jerzy. „Miejsce Broniewskiego w socrealistycznych antologiach”. Broniewski: Warszawa - Katowice 2009. Pod red. Mariusza Jochemczyka, Sławomira Kędzierskiego, Miłosza Piotrowiaka i Macieja Tramera. Warszawa - Katowice: Agencja Artystyczna „Para”, 2009: 176-186.

Szymańska Irena. „Miał duszę hazardzisty”. , Ja jestem kamień”. Wspomnienia o Władystawie Broniewskim. Zebrała i opracowała Mariola Pryzwan. Warszawa: Domena, 2002: 242-243.

Tomasik Wojciech. Stalina wizerunek. Słownik realizmu socjalistycznego. Redakcja naukowa Zdzisław Łapiński, Wojciech Tomasik. Kraków: Universitas, 2004: 320-328.

Tramer Maciej. Brudnopis in blanco. Rzecz o poezji Władysława Broniewskiego. Katowice: Wydawnictwo Uniwersytetu Śląskiego, 2010.

Urbanek Mariusz, Broniewski: miłość, wódka, polityka. Warszawa: Wydawnictwo Iskry, 2011.

Wat Aleksander, Mój wiek. Pamiętnik mówiony. Część pierwsza. Rozmowy prowadził i przedmową opatrzył Czesław Miłosz, do druku przygotowała Lidia Ciołkoszowa. Warszawa: Czytelnik, 1990.

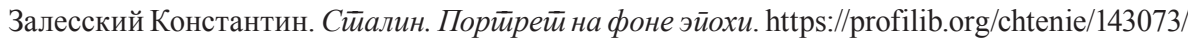
konstantin-zalesskiy-stalin-portret-na-fone-voyny.php (режим доступа 2.01.2020)

Zalesskii Konstantin. Stalin. Portret na fone epokhi. https://profilib.org/chtenie/143073/konstantin-zalesskiy-stalin-portret-na-fone-voyny.php 


\section{Роман Бобрик}

\section{РЕЧ О ГОВОРУ О СТАљИНУ ВЛАДИСЛАВА БРОЬЕВСКОГ}

\section{Резиме}

Поема Говор о Сйаљину важи за типични пример поезије пољског соцреализма. Настала је за потребе антологије поезије посвећене совјетском вођи у част његовог седамдесетог рођендана. Стекла је велику популарност и много пута је прештампавана у часописима, али и као посебна публикација, а због својих речи је постала кантата за мушки хор у музици Алфреда Градштајна. Упркос мишљењу неких истраживача, који су у овој поеми видели покушај да се прикаже шира историјска перспектива, она има јасну панегиричну интонацију. Оно по чему се ова поема разликује од „традиционалних“" панегиричних фирми јесте грађење фабуле о јунаку уз помоћ низа метонимијских алузија. У свом панегиризму Броњевски је отишао и корак даље и успео је да Стаљина поистовети са револуцијом.

Кључне речи: Владислав Броњевски, Јосиф Стаљин, соцреализам, панегирична поезија, револуција.

\section{ANEKS \\ Władysław Broniewski}

\section{Stowo o Stalinie}

\section{I}

Wiek dziewiętnasty gasł, jak gaśnie gazowa latarnia na ulicach fabrycznych osad, wiek maszyn parowych i haseł, wiek, w którym proletariat nie mógł ziemi wysadzić z posad.

Wiek „Manifestu” Marksa, telefonów i telegrafów, klęsk Komuny i zwycięstw Bismarcka, hausse'y i baisse'y, fortun i krachów.

Rosły przędzalnie Manchesterów i Łodzi, skakały akcje żelaznych kolei,

a z suteren, z poddaszy, z przedmieść tłum nadchodził z piersią nagą i z pieśnią nadziei. 
Pieśni Pottiera! w krwawej glorii dalej szum pokoleniom!

„Rewolucja — to parowóz historii” powiedział Marks, zdziałał Lenin.

Wiek dziewiętnasty gasł, jak lampa gazowa w oddali. Zrodzony wśród walki klas, lat dwadzieścia miał Stalin.

II

Chwała tym, co się nie ulękną historii, jak strasznej bajki! Życie burzliwe, życie piękne, od Kaukazu do tundry i tajgi!

Ciszo więzienna, kłamiesz! Wrą w głębokościach zaskórne wody. Zwiastuny burzy własną krwią znaczą drogę swobody.

To nic, że sztandar bojowy padł na demonstrantów w Tyflisie iskra, rzucona w Rosję i w świat, nie gaśnie, żarzy się, tli się.

Dziewięćset piąty rok - to próg, Październik - drzwi otwarte.

Szóstą część świata osaczył wróg, chce zdusić Partię.

Partia jest wszędzie, gdzie gniew i ból, gdzie krzywda proletariatu, i oto świeci, wśród świstu kul, Część Szósta - całemu światu.

III

„Rewolucja - parowóz dziejów”...

Chwała jej maszynistom!

Cóż, że wrogie wiatry powieją?

Chwała płonącym iskrom!

Chwała tym, co wśród ognia i mrozu jak złom granitowy trwali, jak wcielona wola i rozum, jak Stalin. 
Przeleciały watahy lotne białogwardyjskiej konnicy...

Trwał, jak skała samotny, Carycyn.

Parły niemieckie kolumny, waliły stalowym gradem, aż padły pod pięknym i dumnym Stalingradem.

V

Pędzi pociąg historii, błyska stulecie-semafor.

Rewolucji nie trzeba glorii, nie trzeba szumnych metafor.

Potrzebny jest Maszynista, którym jest On:

towarzysz, wódz, komunista Stalin - słowo jak dzwon!

VI

Któż, jak On, przez dziesiątki lat na dziobie okrętu wytrwał?

Szóstej Części przygląda się świat. Bitwa.

Tam — bezrobocia, strajki, głód. $\mathrm{Tu}$ - praca. Natchniony traktor. Tworzy historię zwycięski lud. Chwała faktom!

Któż, jak On, przez dziesiątki lat wiódł ludzkość na krańce dziejów? Jego imię — walczący świat: nadzieja.

Rewolucjo! — któż wiatr powstrzyma, kto ziemię zawróci w biegu? Rewolucjo, tablice praw Rzymu obalamy od Chin po Biegun!

Rewolucjo! siedemdziesiąt lat Stalinowych powiewa nad światem. I rodzi się nowy świat, świat stary pęka jak atom. 
VIII

Miliony ludzi Związku Rad i krajów idących drogą Socjalizmu tworzą świat nowy, niosąc w sercach i na ustach imię STALIN.

Ludowa armia chińska wypędza ze swego kraju przemoc obcą i niewolę pieniądza. Kroczy naprzód z imieniem STALIN.

W Wietnamie, Burmie, na wyspach Malajskich bojownicy wolności, niepodległości i sprawiedliwości walczą przeciw kolonizatorom wołając: STALIN!

Górnicy francuscy trwają w strajkach i wyciągają dłonie na wschód z okrzykiem: STALIN!

Chłopi włoscy zajmują obszarnicze nieużytki i odpędzani gwałtem, wołają: STALIN!

Poeta, wypędzony ze swej ojczyzny za umiłowanie wolności i sprawiedliwości społecznej, piękny poeta chilijski pisze poemat o STALINIE.

Zmiażdżona okrutnie Warszawa dźwiga swe okrwawione cegły tym szybciej z imieniem STALINA.

Wszędzie na świecie, gdzie sięga przemoc pieniądza, bagnet żołdaka i pałka policjanta, ludzie walczą i będą zwyciężali z imieniem STALINA.

Setki milionów ludzi wołają: STALIN! STALIN! STALIN!

IX

Piękne i groźne jest morze, gdy pędzi po falach szkwał, piękny jest w niebie orzeł

nad szczytami urwistych skał,

piękny jest upór i trwanie, piękny jest lot i polot:

morze zatrzyma granit, orła wyprzedzi samolot,

myśli wyprzedzą czyny, czyny legną opoką...

Chwała imieniu Stalina!

Pokój światu, pokój...

(Cyt. wg: Broniewski 1997: 50-56) 